\title{
Influence of Cultivation Conditions on the Production of a Thermostable Extracellular Lipase from Amycolatopsis Mediterranei DSM 43304
}

\author{
Dharmdendra Dheeman \\ Technological University Dublin, dharmendra.dheeman@student.dit.ie \\ Jesus Maria Frias \\ Technological University Dublin, Jesus.Frias@tudublin.ie \\ Gary Henehan \\ Technological University Dublin, gary.henehan@tudublin.ie
}

Follow this and additional works at: https://arrow.tudublin.ie/schfsehart

Part of the Biochemistry Commons

\section{Recommended Citation s10295-009-0643-7 \\ This Article is brought to you for free and open access by the School of Food Science and Environmental Health at ARROW@TU Dublin. It has been accepted for inclusion in Articles by an authorized administrator of ARROW@TU Dublin. For more information, please contact arrow.admin@tudublin.ie, aisling.coyne@tudublin.ie, gerard.connolly@tudublin.ie. \\ Funder: ABBEST Research Scholarship,Technological University Dublin (PB 03557/2007).}

Dheeman D.S., Frias J.M, Henehan, G.T.M. (2010) Influence of Cultivation Conditions on the Production of a Thermostable Extracellular Lipase from Amycolatopsis Mediterranei DSM 43304. Journal of Industrial Microbiology \& Biotechnology, 37, (1),pp. 1-17. doi:10.1007/s10295-009-0643-7 doi:10.1007/

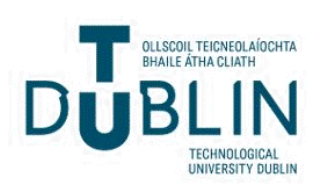


1 Influence of cultivation conditions on the production of a thermostable extracellular

2 lipase from Amycolatopsis mediterranei DSM 43304

3

4 Dharmendra S. Dheeman, Jesus M. Frias and Gary T. M. Henehan*

5

6 School of Food Science and Environmental Health, Dublin Institute of Technology, Cathal

7 Brugha Street, Dublin 1, Ireland.

8

9

10

11

$12{ }^{*}$ Corresponding Author:

13 E-mail: gary.henehan@dit.ie

14 Tel: +35314024408

$15 \quad$ Fax: +35314024495

16

17

18

19

20

21

22 


\section{Abstract}

Among several lipase producing actinomycete strains screened, Amycolatopsis mediterranei DSM 43304 was found to produce a thermostable, extracellular lipase.

Culture condition and nutrient source modification studies involving carbon sources, nitrogen sources, incubation temperature and medium $\mathrm{pH}$ were carried out. Lipase activity of $1.37 \pm 0.103 \mathrm{IU} / \mathrm{ml}$ of culture medium was obtained in $96 \mathrm{~h}$ at $28^{\circ} \mathrm{C}$ and $\mathrm{pH} 7.5 \mathrm{using}$ linseed oil and fructose as carbon sources and a combination of phytone peptone and yeast extract $(5: 1)$ as nitrogen sources. In optimal culture conditions the lipase activity was

31 enhanced 12-fold with a 2-fold increase in lipase specific activity. The lipase showed maximum activity at $60{ }^{\circ} \mathrm{C}$ and $\mathrm{pH}$ 8.0. The enzyme was stable between $\mathrm{pH} 5.0-9.0$ and temperatures up to $60^{\circ} \mathrm{C}$. Lipase activity was significantly enhanced by $\mathrm{Fe}^{3+}$ and strongly inhibited by $\mathrm{Hg}^{2+} . \mathrm{Li}^{+}, \mathrm{Mg}^{2+}$ and PMSF significantly reduced lipase activity, whereas other metal ions had no significant effect at $0.01 \mathrm{M}$ concentration. A. mediterranei DSM 43304 lipase exhibited remarkable stability in the presence of a wide range of organic solvents at $25 \%(\mathrm{v} / \mathrm{v})$ concentration for $24 \mathrm{~h}$. These features render this novel lipase attractive for potential biotechnological applications in organic synthesis reactions.

Keywords: Amycolatopsis mediterranei; Screening; Organic solvent-tolerant;

41 Thermostable; Lipase

42 


\section{Introduction}

46 Lipases (triacylglycerol acylhydrolases E.C.3.1.1.3) are serine hydrolases of considerable physiological significance and industrial potential [46]. Interest in lipases has greatly increased in recent years, mainly because they present a broad range of biotechnological applications due to their unique characteristics of substrate specificity, regio-specificity and chiral-selectivity [41]. Many microorganisms, including bacteria, yeast, and fungi, have been shown to secrete lipases during their growth on hydrophobic substrates [25]. Among lipases of various origins, those from bacteria show the highest degree of versatility, reactivity and stability in the catalysis of reactions in organic solvents [19]. Lipase applications range from the hydrolysis of fats in wastewaters to the synthesis of chiral pharmaceutical intermediates [42]. These applications often require harsh reaction conditions e.g. high temperatures may be required to either favour stereoselectivity or solubilise high melting point lipids [17]. Biocatalysis with lipases is often carried out in organic solvents to promote synthetic reactions by reducing water activity. Many lipases lose activity in organic solvents, and therefore, there is an ongoing interest in lipases that are solvent-tolerant [7]. Despite the advantages of biocatalysis in organic solvent based systems, the catalytic activities of enzymes in these systems are typically much lower than in aqueous solutions [43]. Currently, since microbial lipases do not have the desirable combination of thermostability and stability in both hydrophobic and hydrophilic organic solvents, the search for new lipases is required [31, 33]. There are two main strategies for obtaining lipases with improved properties either protein engineering of currently known lipases [40] or the search for novel lipolytic activities in previously unexplored 
microorganisms [11]. As each industrial application requires specific properties of lipases, there is still an active interest in finding novel lipases for specific applications. To date, a large number of lipases from filamentous fungi, yeasts and unicellular bacteria have been extensively studied, both from the biochemical and from genetic point of view [8]. However, despite their high biotechnological potential for the production of secondary metabolites and enzymes, the actinomycetes have not been widely studied for lipase production $[1,30,50]$.

The present paper deals with the screening of lipase producing actinomycete strains and the culture conditions for optimum enzyme production by a selected strain of Amycolatopsis mediterranei DSM 43304. Medium composition, initial $\mathrm{pH}$, temperature, and time of incubation were examined for the optimization of lipase production. Lipase characteristics with respect to the optimal temperature and $\mathrm{pH}$ for both activity and stability are examined. We also characterize the activity and stability of the lipase in the presence of various organic solvents, metal ions, detergents and inhibitors. To our knowledge, the present work is the first report of an organic solvent-tolerant lipase from the genus Amycolatopsis.

\section{Materials and methods}

\subsection{Materials}

Analytical reagent grade chemicals were purchased from commercial sources at the highest purity. Unless mentioned otherwise, all culture media and chemicals used were from Sigma (Dublin, Ireland). Phytone peptone was obtained from BBL Microbiology Systems (Cockeysville, MD, USA) and Bacto-peptone was obtained from Difco Laboratories (Detroit, MI, USA). Natural oils were purchased from the local retail in Dublin.

\subsection{Microorganisms}


91 Newcastle University, UK.

\subsection{Culture conditions} rotary shaker $(130 \mathrm{rpm})$ at $28^{\circ} \mathrm{C}$.

Actinomycete strains were obtained from Divisional Culture Collection, School of Biology,

\subsection{Maintenance of microorganisms}

Actinomycete strains were grown on GYM agar slants (g/l: glucose $4.0 \mathrm{~g}$; yeast extract 4.0 g; malt extract $10 \mathrm{~g} ; \mathrm{CaCO}_{3} 2.0 \mathrm{~g}$; agar $12.0 \mathrm{~g}$; $\mathrm{pH}$ 7.2). The working stock cultures were maintained and stored on GYM slants at $4{ }^{\circ} \mathrm{C}$.

The composition of basal medium used was (g/l): $\mathrm{NaNO}_{3} 0.5 \mathrm{~g} ; \mathrm{KCl} 0.5 \mathrm{~g} ; \mathrm{MgSO}_{4} 7 \mathrm{H}_{2} \mathrm{O}$ $0.5 \mathrm{~g} ; \mathrm{KH}_{2} \mathrm{PO}_{4} 2.0 \mathrm{~g}$; yeast extract $1.0 \mathrm{~g}$; and Bacto-peptone $5.0 \mathrm{~g}$. The $\mathrm{pH}$ was adjusted to 7.2 with $1 \mathrm{M} \mathrm{NaOH}$ or $1 \mathrm{M} \mathrm{HCl}$. Then $1.0 \%$ (v/v) olive oil was added. Media were sterilized for $15 \mathrm{~min}$ at $121^{\circ} \mathrm{C}$ at $15 \mathrm{psi}$. Submerged microbial cultures were incubated in $250 \mathrm{ml}$ Erlenmeyer flasks containing $50 \mathrm{ml}$ of basal medium with $5 \mathrm{ml}$ inoculum on a

\subsection{Rhodamine B agar screening}

The primary screening for the detection of lipolytic activity on solid media was carried out on rhodamine B agar (RBA) as described by Kouker and Jaeger [29] with some modifications. The growth medium containing $0.9 \%(\mathrm{w} / \mathrm{v})$ peptone water, $0.25 \%(\mathrm{w} / \mathrm{v})$ of yeast extract, $2 \%(\mathrm{w} / \mathrm{v})$ of agar, was adjusted to $\mathrm{pH} 7.2$, autoclaved and cooled to $60{ }^{\circ} \mathrm{C}$. Then, filter sterilized rhodamine B stock solution $(1.0 \mathrm{mg} / \mathrm{ml})$ in distilled water was added to a substrate lipoidal emulsion to yield a final concentration of $0.001 \%(\mathrm{w} / \mathrm{v})$. The substrate lipoidal emulsion consisted of $1.5 \%$ (w/v) olive oil with $0.25 \%$ (v/v) Tween 80 in distilled water that was sterilized by autoclaving. The resulting mixture of lipoidal emulsion with growth medium (1:10) was vigorously stirred to emulsify for $15 \mathrm{~min}$. The medium 
113 was allowed to stand for $10 \mathrm{~min}$ at $60^{\circ} \mathrm{C}$ to reduce foaming before pouring $20 \mathrm{ml}$ of

114 medium into plastic petri plates. Fresh RBA plates were spot inoculated with $72 \mathrm{~h}$-old

115 actinomycete cultures in GYM broth (g/l: glucose $4.0 \mathrm{~g}$; yeast extract $4.0 \mathrm{~g}$; malt extract 10

$116 \mathrm{~g} ; \mathrm{pH}$ 7.2) and incubated at $28^{\circ} \mathrm{C}$ for 6 days. The plates with visible growth were UV

117 irradiated $(350 \mathrm{~nm})$. Lipase production was identified as orange fluorescence under UV

118 light.

$119 \quad 2.6$ Screening in submerged fermentation broth

120 For screening in submerged cultivation conditions, $50 \mathrm{ml}$ of basal medium in $250 \mathrm{ml}$

121 Erlenmeyer flasks was inoculated with $5 \mathrm{ml}, 72$ h-old actinomycete culture in GYM broth

122 and incubated at $28{ }^{\circ} \mathrm{C}$ on a reciprocal shaker $(130 \mathrm{rpm})$. After $96 \mathrm{~h}$, samples were

123 processed for lipase activity assay. One $\mathrm{ml}$ of culture was centrifuged at $10,000 \times \mathrm{g}$, at $4{ }^{\circ} \mathrm{C}$,

124 for 10 min to obtain a cell free supernatant. The clear supernatant was filtered through 0.2

$125 \mu \mathrm{m}$ filter before lipase activity assay.

126

127

128

130

131

\subsection{Spectrophotometric $p$-NPP assay}

Lipase activity was quantitatively assayed in cell free supernatant using $p$-nitrophenyl palmitate ( $p$-NPP) as substrate. This assay was performed as described by Winkler and Stuckman [55] with some modifications. A stock solution of $p$-NPP was freshly prepared in 2-propanol at a concentration of $0.3 \%(\mathrm{w} / \mathrm{v})$. This solution (Solution A) was subjected to 3 min sonication $(135 \mathrm{~W}, 42 \mathrm{kHz}$, Branson 5510E-MT). Then, $900 \mu \mathrm{l}$ of 1:20 dilution of the substrate stock solution A in solution B (0.1\% (w/v) gum arabic, 0.4\% (v/v) Triton X100 in distilled water) with $50 \mu 1$ of appropriate buffer were preincubated for $2 \mathrm{~min}$ at the assay temperature before adding $50 \mu 1$ of enzyme sample. This mixture was incubated at the assay temperature for $10 \mathrm{~min}$, and the reaction was terminated by addition of $2 \mathrm{ml}$ of $0.2 \mathrm{M}$ 
$136 \mathrm{Na}_{2} \mathrm{CO}_{3}$ solution. Released $p$-nitrophenol ( $p$-NP) was immediately determined by

137 measuring the absorbance at $410 \mathrm{~nm}$ in a Unicam UV-VIS spectrophotometer (Model UV2

138 2000E, Cambridge, UK). Appropriate blanks were used to subtract the absorbance

139 corresponding to the reaction mixture other than that produced by the specific hydrolysis of

$140 p$-NPP. The molar extinction coefficient of $p$-NP $\left(\varepsilon_{410 \mathrm{~nm}}=16,900 \mathrm{M}^{-1} \mathrm{~cm}^{-1}\right)$ was estimated

141 from the absorbance of standard solutions of $p$-NP. One international unit of lipase activity

142 was expressed as the amount of enzyme liberating $1 \mu \mathrm{M}$ of $p$-NP per minute under the

143 conditions of the assay.

$144 \quad 2.8$ Biomass concentration analysis

145 After centrifugation at $10,000 \times g$, at $10{ }^{\circ} \mathrm{C}$, for $10 \mathrm{~min}$ and washing the pellet in $0.9 \%(\mathrm{w} / \mathrm{v})$

$146 \mathrm{NaCl}$ solution, the pellet of $5 \mathrm{ml}$ suspension sample was dried to a constant weight at $80{ }^{\circ} \mathrm{C}$

147 for $48 \mathrm{~h}$ and the dry biomass weight was determined gravimetrically.

$148 \quad 2.9$ Statistical analysis

149 Data were analyzed using analysis of variance. In all these cases the analyses were

150 conducted using SPSS (version 15.0) using the procedure of general linear model (Tukey

151 test). The level of tested significance was at $p \leq 0.05$.

152 3. Time course of lipase production by A. mediterranei DSM 43304

153 Time course of lipase production was studied in the basal medium using shake flask

154 cultures. A $10 \%(\mathrm{v} / \mathrm{v})$ of $72 \mathrm{~h}$-old inoculum grown in GYM broth was added to $50 \mathrm{ml}$

155 medium, in a $250 \mathrm{ml}$ Erlenmeyer flask and incubated at $130 \mathrm{rpm}$ on a rotary shaker, at 28

$156{ }^{\circ} \mathrm{C}$. Samples were analyzed at $24 \mathrm{~h}$ intervals to determine $\mathrm{pH}$, dry biomass and lipase

157 activity in the culture supernatant. The effects of the cultivating conditions in shake flask

158 experiments are commonly investigated by subjecting the microorganism to different 
159

160

$161\left(20-45^{\circ} \mathrm{C}\right)$ and initial values of $\mathrm{pH}(5.0-9.0)$. The effect of inoculum size on lipase

162

environmental conditions [56]. In the present work the effect of initial $\mathrm{pH}$ and incubation temperature on the culture was studied using shake flask cultures at different temperatures production was investigated by varying culture inoculum size from $2 \%$ to $12 \%$ of total volume. All experiments were carried out at least in triplicate.

\section{Nutritional factors affecting lipase production by $A$. mediterranei DSM 43304}

The general procedure for cultivation was as follows: 10\% (v/v) of $72 \mathrm{~h}$-old inoculum grown in GYM broth was inoculated into $50 \mathrm{ml}$ of culture medium and incubated at $28{ }^{\circ} \mathrm{C}$ for $96 \mathrm{~h}$. The culture was harvested by centrifugation at $10,000 \times g, 4{ }^{\circ} \mathrm{C}$ for $10 \mathrm{~min}$. The cell free supernatant was filtered ( $0.2 \mu \mathrm{m}$ filter, Millipore) before spectrophotometric determination of lipase activity. Each experiment was carried out in triplicate.

\subsection{Effect of inducers on lipase production}

To determine the effects of substrate related compounds, the olive oil in the basal medium was substituted with natural oils (jojoba, corn, cottonseed, grapeseed, groundnut, linseed, rapeseed, soybean and sunflower) at $1.0 \%(\mathrm{v} / \mathrm{v})$ concentration.

\subsection{Effect of surfactants on lipase production}

The following detergents were added to the basal medium as lipase inducers, replacing olive oil, at $0.5 \%$ (w/v) concentration: Span 40, Span 65, Span 80, Tween 20, Tween 21, Tween 40, Tween 80 and Triton X100.

\subsection{Effect of carbon source additives on lipase production}

In order to elucidate the effect of carbon source additives on lipase production, olive oil in the basal medium was combined with $1.0 \%(\mathrm{w} / \mathrm{v})$ of the following sugars: arabinose, 
181 dextrin, fructose, galactose, glucose, lactose, mannitol, maltose, maltotetraose, mannose,

182 raffinose, rhamnose, sorbitol, sucrose, starch and xylose.

$183 \quad 4.4$ Effect of organic nitrogen sources on lipase production

184 To assess the effects of organic nitrogen source in combination with yeast extract on lipase

185 production, Bacto-peptone in the basal medium, was substituted with phytone peptone,

186 yeast extract, corn steep liquor, beef extract, skim milk, wheat peptone, fish peptone,

187 tryptone, casein hydrolysate, casein, and wheat gluten, each at a concentration of $0.5 \%$

$188(\mathrm{w} / \mathrm{v})$.

$189 \quad \mathbf{4 . 5}$ Effect of phytone peptone and yeast extract on lipase production

190 Phytone peptone with yeast extract was the best nitrogen source for A. mediterranei DSM

19143304 lipase production. The influence of the amount of phytone peptone and yeast extract

192 in basal medium was tested by varying their concentrations in the basal medium.

$193 \quad 4.6$ Effect of inorganic nitrogen sources on lipase production

194 In order to assess the effects of inorganic nitrogen sources on lipase production, $\mathrm{NaNO}_{3}$ in

195 the basal medium was substituted with: $\mathrm{NH}_{4} \mathrm{Cl},\left(\mathrm{NH}_{4}\right)_{2} \mathrm{SO}_{4},\left(\mathrm{NH}_{4}\right)_{2} \mathrm{HPO}_{4}, \mathrm{NH}_{4} \mathrm{H}_{2} \mathrm{PO}_{4}$,

$196 \mathrm{CH}_{3} \mathrm{COONH}_{4}, \mathrm{NH}_{4} \mathrm{NO}_{3}$ and urea, each at $0.05 \%(\mathrm{w} / \mathrm{v})$.

$197 \quad 4.7$ Effect of metal ions on lipase production

198 Metal ions individually and in combination were tested for their effects on optimal lipase

199 production in basal medium. $\mathrm{Mg}^{2+}, \mathrm{Ca}^{2+}$ and $\mathrm{Fe}^{3+}$ salts were incorporated into the basal

200 medium at $0.05 \%(\mathrm{w} / \mathrm{v})$ concentration. Also combinations of $\mathrm{Mg}^{2+}$ and $\mathrm{Ca}^{2+}, \mathrm{Ca}^{2+}$ and $\mathrm{Fe}^{3+}$,

201 and $\mathrm{Mg}^{2+}$ and $\mathrm{Fe}^{3+}$ were added at individual final concentration of $0.025 \%(\mathrm{w} / \mathrm{v})$ to assess

202 their cumulative effect on lipase production. 


\subsection{Effect of temperature activity and stability}

205 Lipase activity was measured at various temperatures $\left(30-80^{\circ} \mathrm{C}\right)$ under standard assay conditions. Thermal stability of the enzyme was investigated by preincubating the enzyme at various temperatures $\left(30-80^{\circ} \mathrm{C}\right)$ for $3 \mathrm{~h}$. The samples were then assayed for residual

208 lipase activity under standard assay conditions.

\section{$209 \quad \mathbf{5 . 2}$ Effect of pH on activity and stability}

210 The effect of $\mathrm{pH}$ on lipolytic activity was determined in the following buffers (all at 50

$211 \mathrm{mM}): \mathrm{HCl}-\mathrm{KCl}(\mathrm{pH} 2.0)$, sodium citrate (pH 3.0), succinate- $\mathrm{NaOH}(\mathrm{pH} 4.0$ and 5.0),

212 sodium phosphate (pH 6.0 and 7.0), Tris- $\mathrm{HCl}(\mathrm{pH} 8.0$ and 9.0) and glycine- $\mathrm{NaOH}(\mathrm{pH}$

213 10.0). The optimum $\mathrm{pH}$ obtained was used for investigation of thermostability and other

214 parameters. These buffers were used to determine $\mathrm{pH}$ stability of the crude lipase

215 preparation. A mixture (1:1) of crude enzyme and buffers $(0.1 \mathrm{M})$ was incubated for $24 \mathrm{~h}$ at

$2164{ }^{\circ} \mathrm{C}$ and the standard enzyme assay described previously was performed. The residual

217 activities were calculated by comparison with the activity in $50 \mathrm{mM}$ Tris- $\mathrm{HCl}$ buffer, $\mathrm{pH}$

218 8.0, without pre-incubation.

\section{$219 \quad 5.3$ Effect of organic solvents on lipase stability}

220 The effect of various polar and non-polar organic solvents with different $\log P$ values on

221 crude lipase stability was investigated. One $\mathrm{ml}$ of organic solvent was added to $3.0 \mathrm{ml}$ of 222 cell free supernatant and incubated at $30^{\circ} \mathrm{C}$, while shaking at $200 \mathrm{rpm}$ for $24 \mathrm{~h}$ to ensure

223 the continuous mixing of enzyme and the solvents. The enzyme stability was expressed as

224 the remaining activity relative to the control without solvent.

\section{$225 \quad 5.4$ Effect of metal ions and effector molecules on lipase stability}


226 The effect of metal ions and effector molecules on lipase activity was studied at $\mathrm{pH} 8.0$ by 227 incubating the enzyme in presence of $1 \mathrm{mM}$ of metal ions $\left(\mathrm{Ag}^{+}, \mathrm{Ba}^{2+}, \mathrm{Co}^{2+}, \mathrm{Li}^{+}, \mathrm{Mn}^{2+}, \mathrm{Ni}^{2+}\right.$, $228 \mathrm{~Pb}^{2+}, \mathrm{Ca}^{2+}, \mathrm{Fe}^{3+}, \mathrm{Cu}^{2+}, \mathrm{Zn}^{2+}, \mathrm{Mg}^{2+}$ and $\mathrm{Hg}^{2+}$ ) and effectors (PMSF, EDTA, SDS, $\mathrm{NH}_{4}{ }^{+}$and

229 urea). Incubation was carried out at $60{ }^{\circ} \mathrm{C}$ for $10 \mathrm{~min}$ and assayed for lipase activity.

230 Residual lipase activity was calculated as a percentage of that without metal ions/effectors.

231 6. Results and discussion

$232 \quad 6.1$ Screening of strains for lipase production

233 Figure 1 shows rhodamine B agar screening for lipase production by actinomycete strains.

234 Except for Amycolatopsis coloradensis DSM 44225 and Streptomyces aureoverticillatus

235 NRRL B-3326, all actinomycete strains showed brilliant pink-red/orange fluorescence on

236 UV irradiation of RBA plates. Lipase screening in basal medium using shake flask cultures

237 showed presence of lipolytic activity in cell free supernatants prepared from actinomycete

238 culture broths (Table 1). Of 18 actinomycetes strains, 7 showed more than $0.05 \mathrm{IU} / \mathrm{ml}$ at 96

239 h. Among these, A. rubida DSM 44637, S. rochei DSM 40231 and S. griseus subsp.

240 griseus DSM 40236 produced the highest activities at $0.149 \pm 0.017 \mathrm{IU} / \mathrm{ml}, 0.141 \pm 0.004$

$241 \mathrm{IU} / \mathrm{ml}$ and $0.116 \pm 0.010 \mathrm{IU} / \mathrm{ml}$, respectively.

242 Actinomycetes are Gram-positive bacteria with a remarkable genetic repertoire for

243 producing secondary metabolites and enzymes. Despite their high biotechnological

244 potential, the actinomycetes have not been widely investigated for lipase activity $[8,13$,

245 50]. Only a few studies have been reported on their esterase and lipolytic activities [6].

246 Large et al. described lipase activity associated with the cells of different Streptomyces sp.,

247 which were found to be induced and enhanced by the presence of a lipid substrate in the

248 fermentation medium [30]. Gandolfi et al. carried out carboxylesterase screening of 
Streptomyces strains on solid media using tributyrin, triolein and Tween 60 as substrate and

250 evaluated their cell bound and extracellular hydrolytic activities [18]. Cardenas et al.

251 isolated novel actinomycetes and fungal strains and demonstrated their lipolytic activity by

252 employing screening techniques on solid and liquid media using agar plates supplemented

253 with emulsified olive oil and tributyrin [8]. The present investigation identified a number of

254 actinomycetes producing significant extracellular lipolytic activities.

\section{5 \\ 6.2 Effect of culture conditions on lipase production by $A$. mediterranei DSM 43304}

256 The preliminary characterization of extracellular lipases from actinomycete strains in terms

257 of pH optimum, temperature optimum and thermostability identified the lipase from $A$.

258 mediterranei DSM 43304 as the most thermostable and analysis by zymography indicated

259 presence of a single lipase in extracellular culture broth (data not shown). Therefore, $A$.

260 mediterranei DSM 43304 was selected for further characterization and various culture

261 parameters were studied to improve lipase production.

262

263

264

265

\subsubsection{Time course of lipase production}

It has been reported that the lipase synthesis of $S$. exfoliatus M11 and S. coleicolor A3(2) is growth phase dependent [47]. Therefore, the time course of lipase synthesis in basal medium by $A$. mediterranei DSM 43304 was monitored by measurement of lipase activity, dry biomass and $\mathrm{pH}$. Figure 2 shows that substantial lipase production commenced at $24 \mathrm{~h}$ and reached a maximum at $96 \mathrm{~h}$. Further incubation lead to increase in lipase activity with a slow decrease in the lipase specific activity (data not shown). Loss of lipase specific activity may be due to secretion of other proteins at the late logarithmic phase leading to an apparent decrease in lipase specific activity. Swift et al. reported that once cell densities have reached certain threshold level, generally in the late logarithmic phase, the expression 
272 of genes encoding exoproteins and secretion system is induced [49]. There was a shift in $273 \mathrm{pH}$ from $7.20 \pm 0.02$ to $8.02 \pm 0.057$ during the first $24 \mathrm{~h}$ of incubation, rising to $\mathrm{pH} 8.96 \pm$ $274 \quad 0.11$ at $96 \mathrm{~h}$.

\subsubsection{Effect of inoculum size on lipase production}

276 Low inoculum density may give insufficient biomass causing reduced product formation,

277 whereas a higher inoculum may produce too much biomass leading to poor product

278 formation [37]. Increased enzyme production was observed with the increase in inoculum 279 size and showed maximum enzyme activity $(0.105 \pm 0.003 \mathrm{IU} / \mathrm{ml})$ and biomass $(5.8 \pm 0.6$ $280 \mathrm{mg} / \mathrm{ml}$ ) production at $96 \mathrm{~h}$ with $10 \%$ inoculum (Table 2). Further increases in inoculum size 281 resulted in decreased enzyme synthesis, probably due to nutrient limitation.

$282 \quad$ 6.2.3 Effect of incubation temperature on lipase production

283 Temperature may affect lipase production [34]. Submerged fermentation was carried out at $284 \quad 20-45{ }^{\circ} \mathrm{C}$ with $10 \%$ inoculum for $96 \mathrm{~h}$ to evaluate the effect of incubation temperatures on 285 growth and enzyme production. Maximum enzyme and biomass production was observed 286 in the mesophilic range at $28-35^{\circ} \mathrm{C}$ (Figure 3 ). The optimal temperature determined for 287 lipase production by $A$. mediterranei DSM $43304\left(28^{\circ} \mathrm{C}\right)$ is comparable to those of $S$. 288 erythraea, S. clavuligerus [30] and Psedomonas aeruginosa PseA [45].

\section{$289 \quad$ 6.2.4 Effect of initial medium $\mathbf{p H}$ on lipase production}

290 The $\mathrm{pH}$ of the culture broth was found to be one of the most critical environmental

291 parameters affecting the growth and enzyme production by A. mediterranei DSM43304.

292 The results showed maximum biomass and lipase production at initial medium $\mathrm{pH}$ of 7.5

293 (Figure 4). Lipase activity dropped significantly at alkaline and acidic pH of 9.0 and 5.0, 294 respectively. The optimum $\mathrm{pH}$ (7.5) is close to optimum $\mathrm{pH}$ of 7.0 for lipase production by 
295 Candida sp. [52] but is lower than that of other reported lipase-producing organisms.

296 Bacillus mycoides showed optimal lipase production at $\mathrm{pH}$ 8.0. [53] whereas, maximal

297 lipase production by $A$. terreus was observed at an initial medium $\mathrm{pH}$ of 9.0 [22]. The $\mathrm{pH}$

298 change observed during growth of the organism may affect the enzyme stability in the 299 medium [23].

300

301

302

303

304

305 311 sole source of carbon in the medium $[34,38,44,51]$.

312 Surfactants as lipase inducers in the medium did not enhance lipase production when

\subsubsection{Effect of inducers on lipase production}

Natural oils as carbon sources had different effects on lipase production. The results (Table

3 ) indicate that all lipidic sources supported lipase activity, ranging from $0.014 \pm 0.001$

$\mathrm{IU} / \mathrm{ml}$ to $0.128 \pm 0.004 \mathrm{IU} / \mathrm{ml}$. The highest lipase production $(0.128 \pm 0.004 \mathrm{IU} / \mathrm{ml})$ and biomass $(16.0 \pm 1.4 \mathrm{mg} / \mathrm{ml})$ was found using linseed oil followed by sunflower oil $(0.104 \pm$ $0.004 \mathrm{IU} / \mathrm{ml}$ ). Soybean oil gave the lowest lipase activities. There are very few examples in literature where linseed oil has been used as a lipid source for lipase production. Linseed oil was tested as one of the oils for lipase production by Burkholderia cepacia [44] and in case of P.camembertii Thom PG-3 it was found to be the second best inducer for lipase production [51]. Natural oils such as soybean, corn, sunflower, olive, palm and cotton seed oils, amongst others, are cited as inducers of lipase production, comprising at times, the compared to olive oil (Table 3). Similar effects were reported on lipase production in Rhizopus sp. BTNT-2 [3] and Yarrowia lipolytica [15]. Surfactants do not always increase lipolytic enzyme production [35] and their effect varies with microorganism, surfactant type and its concentration $[15,52]$. However, the addition of surfactant to the culture 
317 medium has been shown to increase the secretion of lipolytic enzymes in a number of

318 microorganisms, attributable to alteration of cell permeability leading to increased protein

319 secretion or to surface effects on cell bound enzymes [52]. A wide variety of surfactants

320 like Tweens, Triton, SDS, PEG and gum arabic have been studied by different investigators

$321[15,35,52]$.

$322 \quad$ 6.2.6 Effect of carbon source additives on lipase production

323 The effect of of carbon source in the basal medium on lipase production by $A$. mediterranei

324 DSM43304 is shown in Table 4. Lipase production and biomass was significantly enhanced

325 with the addition of sugars to the basal medium in most cases. Fructose gave the highest

326 activity of $0.467 \pm 0.007 \mathrm{IU} / \mathrm{ml}$ with biomass of $11.2 \pm 0.9 \mathrm{mg} / \mathrm{ml}$, whereas lactose

327 produced the highest biomass of $14.9 \pm 0.4 \mathrm{mg} / \mathrm{ml}$ with lipase activity of $0.399 \pm 0.021$

$328 \mathrm{IU} / \mathrm{ml}$. Lipase production was increased 3-fold with lactose, sorbitol, maltose and xylose as

329 carbon source additives. However, addition of arabinose, dextrin, and sucrose had no

330 significant effect on lipase production and showed significant decrease in biomass. In

331 contrast, addition of rhamnose showed increased biomass with no significant improvement

332 in lipase activity. A range of different carbon sources (i.e. carbohydrates, alcohols, acids,

333 lipids) have been reported to support both growth of lipolytic enzyme producers and

334 lipase/esterase production [4, 22]. Although lipidic carbon sources seem to be generally

335 essential for obtaining a high enzyme yield, some authors have indicated good results in the

336 absence of fats and oils [34], whereas in some cases, a mixture of compounds has been

337 proposed as optimum carbon source $[14,18]$. Similar to the present study, fructose as

338 carbon source was found to significantly increase lipase activity in Issatchenkia orientalis

339 [11]. Lactose was reported to support high to moderate lipase production in various 
340 microorganisms [26], which is similar to the present study where lactose led to a significant

341 increase in lipase production.

\subsubsection{Effect of nitrogen sources on lipase production}

343 Nitrogen sources, including organic nitrogen and inorganic nitrogen sources play an

344 important role in the biosynthesis of lipase [51]. Lipase production and biomass were found 345 to be highest with phytone peptone $(0.131 \pm 0.021 \mathrm{IU} / \mathrm{ml})$ and yeast extract $(0.104 \pm 0.005$

$346 \mathrm{IU} / \mathrm{ml})$ as organic nitrogen source followed by Bacto-peptone $(0.071 \pm 0.002 \mathrm{IU} / \mathrm{ml})$ and 347 cornsteep liquor $(0.061 \pm 0.006 \mathrm{IU} / \mathrm{ml})$ (Table 5). Significant biomass was produced with 348 beef extract $(8.4 \pm 0.7 \mathrm{mg} / \mathrm{ml})$ and tryptone $(8.1 \pm 0.9 \mathrm{mg} / \mathrm{ml})$ as nitrogen source but the 349 lipase activities obtained were low. Wheat gluten gave the lowest lipase $(0.017 \pm 0.001$ $350 \mathrm{IU} / \mathrm{ml}$ ) yield followed by casein and casein hydrolysate. Similar studies were carried out by 351 other investigators to find the best nitrogen source for lipase production $[3,22]$. Soybean 352 meal was reported to be the best nitrogen source for lipase production by $P$. camembertii $353 P G-3[51]$. Higher lipase production was reported using yeast extract as nitrogen source for 354 Saccharomyces cerevisiae [48]. Contrary to the present results, casein and corn gluten were 355 the best sources for lipase production by A. terreus [22].

356 Phytone peptone with yeast extract was identified as the best nitrogen sources for lipase 357 production by $A$. mediterranei DSM 43304. The effect of different concentrations of 358 phytone peptone and yeast extract on lipase production is shown in Table 5. There was no 359 significant difference in terms of lipase activities and biomass production by different 360 concentrations of phytone peptone and yeast extract in the basal medium. By contrast, a 361 similar study identified a combination of $0.6 \%$ tryptone and $0.2 \%$ yeast extract as the best nitrogen source for lipase production by Bacillus sp. strain 42 [16]. The effect of different 
363 inorganic nitrogen sources showed $\left(\mathrm{NH}_{4}\right)_{2} \mathrm{HPO}_{4}$ as the best inorganic nitrogen source

364 producing maximum lipase activity followed by $\mathrm{NaNO}_{3}$ (Table 6). In agreement with the 365 present observation, higher specific activity of Burkholderia cepacia lipase was observed in 366 presence of $(\mathrm{NH} 4)_{2} \mathrm{HPO}_{4}$ as inorganic nitrogen source followed by $\mathrm{KNO}_{3}$ [44]. Among the 367 inorganic nitrogen sources tested for Psedomonas sp. G6, $\mathrm{NaNO}_{3}$ supported the best lipase 368 production [27]. Urea showed the lowest lipase and biomass yield followed by $\mathrm{NH}_{4} \mathrm{Cl}$.

369 Urea was also reported to be inhibitory for lipase synthesis by P. camembertii Thom PG-3 $370 \quad[51]$.

\section{$371 \quad$ 6.2.8 Effect of metal ions on lipase production}

372 Besides physical and nutritional parameters, metal ions may play an important role in lipase 373 production [39]. The effect of different metal ions and metal ion combinations on lipase 374 production is shown in Table 4. Metal ions did not make any significant difference to lipase 375 activity and biomass production. Contrary to the present results, iron was reported to be 376 critical for the production of lipase by Psedomonas sp. G6 [27] and $\mathrm{Ca}^{2+}$ was reported to 377 have strong stimulatory effect on extracellular lipase production by $P$. fluorescens 2D [36].

378 Similarly, $\mathrm{Ca}^{2+}$ in presence of $\mathrm{Mg}^{2+}$ was reported to produce a significant increase in lipase 379 production by Burkholderia cepacia [44].

\section{$380 \quad$ 6.2.9 Lipase production in modified medium}

381 The extent of improvement in lipase activity yield by fermentation using the optimal 382 culture parameters was investigated. The modified culture medium for lipase production by 383 A mediterranei DSM 43304 consisted of $1 \%(\mathrm{v} / \mathrm{v})$ linseed oil, $1 \%(\mathrm{w} / \mathrm{v})$ fructose, $0.05 \%$ 384 (w/v) $\left(\mathrm{NH}_{4}\right)_{2} \mathrm{HPO}_{4}, 0.05 \%$ (w/v) $\mathrm{KCl}, 0.05 \%$ (w/v) $\mathrm{MgSO}_{4} 7 \mathrm{H}_{2} \mathrm{O}, 0.2 \%$ (w/v) $\mathrm{KH}_{2} \mathrm{PO}_{4}$, $3850.5 \%(\mathrm{w} / \mathrm{v})$ phytone peptone, $0.1 \%(\mathrm{w} / \mathrm{v})$ yeast extract, initial $\mathrm{pH} 7.5$ and the culture was 
386 incubated at $28^{\circ} \mathrm{C}$ for $96 \mathrm{~h}$. The lipase activity produced increased from $0.108 \pm 0.002$

$387 \mathrm{IU} / \mathrm{ml}(3.80 \pm 0.14 \mathrm{IU} / \mathrm{mg})$ in the basal medium to $1.372 \pm 0.103 \mathrm{IU} / \mathrm{ml}(7.27 \pm 0.52$

$388 \mathrm{IU} / \mathrm{mg}$ ) in the modified medium. Thus, a 12-fold increase in lipase activity yield and 2-fold

389 increase in lipase specific activity was achieved by employing newly formulated production 390 medium.

391 7. Characterization of lipase

$392 \quad 7.1$ Effect of temperature on activity and stability

393 The effect of temperature on the activity and stability of lipase is shown in Figure 5. The

394 lipase from A. mediterranei DSM 43304 was found to be quite thermostable with a 395 temperature optimum of $60{ }^{\circ} \mathrm{C}$ at $\mathrm{pH} 8.0$. It retained $90 \%$ of activity at $60{ }^{\circ} \mathrm{C}$ after $3 \mathrm{~h}$

396 incubation and had a half-life of more than $30 \mathrm{~min}$ at $70{ }^{\circ} \mathrm{C}$. High thermal stability of 397 lipolytic activity detected in this study may be useful for several industrial applications.

398 Bacterial lipases generally have temperature optima in the range $30-60^{\circ} \mathrm{C}$. However, 399 reports exist of bacterial lipases with optima both in lower and higher ranges [24]. Thermal 400 stability of a lipase is obviously related to its tertiary structure and is influenced by 401 environmental factors such as $\mathrm{pH}$ and the presence of metal ions [62]. A few thermostable 402 lipases from actinomycetes have been reported. S. fradiae var. k11 was reported to produce 403 a proteolysis-resistant lipase having a temperature optimum of $55^{\circ} \mathrm{C}[60]$ and a 404 thermostable lipase, most active at $50-60^{\circ} \mathrm{C}$, was purified from $S$. rimosus [1]. Two 405 different lipases from S. coelicolor A3(2) were characterized showing temperature optima 406 at $20-30{ }^{\circ} \mathrm{C}(\mathrm{SCO} 1725)$ and $45-55^{\circ} \mathrm{C}(\mathrm{SCO} 7513)$ [12].

\subsection{Effect of pH on activity and stability}


408 Figure 6 shows the effect of $\mathrm{pH}$ on lipolytic activity and stability. The lipase was found to

409 be active over the $\mathrm{pH}$ range 5.0-8.0. Maximal lipolytic activity was at $\mathrm{pH} 8.0$ and showed 410 retention of $88 \%, 98 \%, 95 \%$ and $89 \%$ activity at $\mathrm{pH} 5.0,6.0,7.0$ and 9.0 , respectively. The

411 pH stability profile showed the highest stability at pH 8.0 and 9.0 with $96 \%$ residual

412 activity. The activity was also stable at $\mathrm{pH} 6.0$ and 7.0 showing $94 \%$ residual activity after

$41324 \mathrm{~h}$. The stability of the enzyme in acidic and alkaline $\mathrm{pH}$ suggests its usefulness in

414 industrial applications. Generally, lipases of bacterial origin have neutral or alkaline $\mathrm{pH}$

415 optima with the exception of $P$. fluorescence SIK W1 lipase which has an acidic $\mathrm{pH}$

416 optimum of 4.8 [2]. Most of the lipases characterized from actinomycetes so far show

417 alkaline $\mathrm{pH}$ optima. S. rimosus lipase was reported to show a $\mathrm{pH}$ optimum range of 9.0-

41810.0 [1] and $S$. fradiae var. k11 lipase was most active at pH 9.8 [60]. Similarly, $S$.

419 coelicolor A3(2) lipases showed $\mathrm{pH}$ optima between 7.5-10.0 [12].

7.3 Effect of organic solvents on lipase stability

421 The effect of various organic solvents on the stability of A. mediterranei DSM 43304 lipase

422 is shown in Table 6. The lipase exhibited considerable stability in the presence of polar

423 solvents $(\log P<0.3)$ as well as non-polar hydrophobic solvents $(\log P$ 0.85-6.6) with

424 significant activation observed in most cases. The highest degree of activation was in

425 benzene and toluene. Lipase was significantly activated after $1 \mathrm{~h}$ in $p$-xylene and $n$-hexane

426 showing a $61.9 \%$ and $56.7 \%$ increase in activity, respectively. Further incubation for $24 \mathrm{~h}$

427 led to $28.2 \%$ and $45 \%$ decrease in activation indicating destabilizing effects of these

428 solvents. The lipase was least stable in pyridine and showed $49.8 \%$ residual activity after 24

429 h. Similarly, a destabilizing effect was seen with $t$-butanol, dodecane and DMSO. It has

430 been shown that many enzymes retain activity in organic solvents [59] and have interesting 
431 catalytic properties such as higher thermostability and altered stereoselectivity [54]. Despite

432 many advantages of enzymatic reactions in organic solvents, in most cases the catalytic

433 activity in organic solvents is orders of magnitude lower than in aqueous systems [10]

434 because of diffusional limitations, changes in protein flexibility, or destabilization of the

435 enzyme [28]. A. mediterranei DSM 43304 lipase was activated and stable in DMF,

436 methanol, ethanol, 2-propanol and acetone. Though solvent stability has been reported for a

437 few actinomycete lipases $[5,8,32]$, the high stability and indeed, activation in polar

438 solvents like methanol and ethanol has rarely been observed [8]. S. rimosus lipase was

439 reported to show stimulation of activity upon addition of $2.5 \%(\mathrm{v} / \mathrm{v})$ 1,4-dioxane, THF,

440 acetone and DMF [32]. Similarly, S. coelicolor lipase was found to be stable with different

441 water-miscible solvents and showed 50\% increase in activity in acetone after $18 \mathrm{~h}$ and

442 similar to the present study, significant loss of activity was observed with DMSO, while in

443 contrast, DMF led to almost complete loss of activity [5]. It is reported that polar solvents

444 strip off the essential water molecules from the active site of enzymes [21]. For this reason,

445 use of polar solvents is avoided and hydrophobic solvents are more often employed in non-

446 aqueous enzymology [20]. The polar solvent tolerant lipases therefore appear promising for

447 catalysis in low water media. This property is a novel attribute of $A$. mediterranei DSM

44843304 lipase, which has been reported in few cases [5, 32, 61]. The high stability and

449 activation of $A$. mediterranei DSM 43304 lipase in a wide range of polar and non-polar

450 organic solvents may make it useful for practical applications in synthetic

451 biotransformation reactions.

$452 \quad 7.4$ Effect of metal ions and effectors on lipase stability 
453 The effect of different metal salts and effector molecules on A. mediterranei DSM 43304

454 lipase is shown in Table 7. The crude lipase was strongly inhibited by $\mathrm{Hg}^{2+}$ losing $80 \%$ of 455 activity in 10 min suggesting it is able to alter enzyme conformation as has been reported 456 for other lipases [9]. $\mathrm{Li}^{+}$and $\mathrm{Mg}^{2+}$ also significantly reduced enzyme activity. The other 457 metal ions tested did not produce adverse effect on the activity of the enzyme. Compared to 458 the control, $\mathrm{Ca}^{2+}$ did not cause significant reduction in lipase, even though $\mathrm{Ca}^{2+}$ has been 459 reported to stabilize lipolytic activity $[9,20] . \mathrm{Cu}^{2+}$ has been reported to be a strong inhibitor 460 of lipase activity $[19,26]$, but no inhibition was observed with $\mathrm{Cu}^{2+}$ at a concentration of 1 $461 \mathrm{mM}$ under the conditions tested. Similarly, S. fradiae var. k11 lipase was reported to retain $46299.4 \%$ lipase activity in the presence of $1 \mathrm{mM} \mathrm{Cu}^{2+}$ for $30 \mathrm{~min}[60] . \mathrm{Cu}^{2+}$ did not 463 significantly reduce the lipolytic activity of SCO1725 and SCO7513 from S. coelicolor 464 A3(2) [12]. The lipase activity was unaffected by the metal-chelating agent EDTA 465 indicating that $A$. mediterranei DSM 43304 lipase is probably not a metalloenzyme. The 466 activities of lipases from $S$. rimosus and $S$. fradiae var. k11 have also been reported to be 467 unaffected by EDTA $[1,60]$. The effect of a serine inhibitor PMSF, at $1 \mathrm{mM}$ concentration 468 gave a $15 \%$ reduction in lipase activity possibly suggesting the presence of a hydrophobic 469 lid hindering access to the catalytic site [12]. The extracellular lipase from S. rimosus was 470 found to be marginally affected by $1 \mathrm{mM}$ PMSF showing retention of $90 \%$ of residual 471 activity [1]. Similarly, 89-91\% residual activity was retained in presence of $1 \mathrm{mM}$ PSMF 472 by $S$. coelicolor A3(2) lipases [12]. The lipase showed $88 \%$ retention of activity in presence 473 of $1 \mathrm{mM}$ urea. SDS was found not to affect lipase activity. In agreement with the present 474 study lipase activity was reported to be stable with 79\% residual activity in the presence of $4751 \mathrm{mM}$ SDS by B. cepacia lipase [57], whereas Yarrowia lipolytica lipase showed 
significant inhibition of lipase activity with $1 \mathrm{mM}$ SDS [58]. Contrary to the present results,

477 lipase from $B$. thermoleovorans CCR11 was reported to be completely inhibited by $1 \mathrm{mM}$

478 SDS in $1 \mathrm{~h} \mathrm{[9].}$

\section{Conclusions}

480 A lipolytic actinomycete strain, Amycolatopsis mediterranei DSM 43304 was identified as

481 producing an extracllular organic solvent-tolerant thermostable lipase. A significant 12 -fold 482 increase in lipase activity and 2-fold increase in lipase specific activity was achieved by 483 employing the newly formulated culture medium. The extracellular lipase was highly stable 484 in a broad range of polar and non-polar organic solvents, with maximum enhancement of 485 activity in non-polar solvents. The properties of thermostability, stability and enhancement 486 of activity in organic solvents, and stability with a broad range of effector molecules shows 487 that this lipase may be a promising enzyme for applications in a range of in vitro 488 biotransformation reactions.

\section{Acknowledgements}

490 This work was supported by ABBEST Research Scholarship from Dublin Institute of 491 Technology (PB 03557/2007). The authors want to express their thanks to Prof. Michael 492 Goodfellow and Dr. Amanda L. Jones, School of Biology, Newcastle University, UK for 493 providing the strains for this study.

494 References:

1. Abramic M, Lescic I, Korica T, Vitale L, Saenger W, Pigac J (1999) Purification and properties of extracellular lipase from Streptomyces rimosus. Enzym Microb Technol 25:522-529 
2. Andersson RE, Hedlund GB, Jensson V (1979) Thermal inactivation of a heat resistant lipase produced by the psychrotrophic bacterium Pseudomonas fluorescens. J Dairy Sci 62:361-367

3. Bapiraju KVVSN, Sujatha P, Ellaiah P, Ramana T (2005) Sequential parametric optimisation of lipase production by a mutant strain Rhizopus sp, BTNT-2. J Basic Microbiol 45:257-273

4. Benjamin S, Pandey A (1996) Optimization of liquid media for lipase production by Candida rugosa. Bioresour Technol 55:167-170

5. Bielen A, Cetkovic H, Long PF, Schwab H, Abramic M, Vujaklija D (2009) The SGNH-hydrolase of Streptomyces coelicolor has (aryl)esterase and a true lipase activity. Biochimie 91:390-400

6. Bormann C, Nikoleit K, Potgeter M, Tesch C, Sommer P, Goetz F (1993) Investigation of lipolytic enzymes from Streptomyces. In: DECHEMAmonographs. VCH, Weinheim, Germany, pp 237-247

7. Boutaiba S, Bhatnagar T, Hacene H, Mitchell DA, Baratti JC (2006) Preliminary characterisation of a lipolytic activity from an extremely halophilic archaeon, Natronococcus sp. J Mol Catal B: Enzym 41:21-26 SW, Alvarez E (2001) Novel microbial lipases: catalytic activity in reactions in organic media. Enzym Microb Technol 28:145-154

9. Castro-Ochoa LD, Rodriguez-Gomez C, Valerio-Alfaro G, Ros RO (2005) Screening, purification and characterization of the thermoalkalophilic lipase 
produced by Bacillus thermoleovorans CCR11. Enzyme Microb Technol 37:648654

10. Clark DS (2004) Characteristics of nearly dry enzymes in organic solvents: implications for biocatalysis in the absence of water. Philos T Roy Soc B 359:1299-1307

11. Costas M, Deive FJ, Longo MA (2004) Lipolytic activity in submerged cultures of Issatchenkia orientalis. Process Biochem 39:2109-2114

12. Cote A, Shareck F (2008) Cloning, purification and characterization of two lipases from Streptomyces coelicolor A3(2). Enzym Microb Technol 42:381-388

13. Cruz H, Perez C, Wellington E, Castro C, Servin-Gonzalez L (1994) Sequence of the Streptomyces albus G lipase-encoding gene reveals the presence of a prokaryotic lipase family. Gene 144:141-142

14. Dalmau E, Montesinos JL, Lotti M, Casas C (2000) Effect of different carbon sources on lipase production by Candida rugosa. Enzyme Microb Technol 26:657-663

15. Dominguez A, Deive FJ, Sanroman MA, Longo MA (2003) Effect of lipids and surfactants on extracellular lipase production by Yarrowia lipolytica. J Chem Technol Biotechnol 78:1166-1170

16. Eltaweel MA, Rahman RNZRA, Salleh AB, Basri M (2005) An organic solventstable lipase from Bacillus sp. strain 42. Ann Microbiol 55:187-192

17. Ema T (2004) Rational strategies for highly enantioselective lipase-catalyzed kinetic resolutions of very bulky chiral compounds: Substrate design and hightemperature biocatalysis. Tetrahedron: Asymmetry 15:2765-2770 
18. Gandolfi R, Marinelli F, Lazzarini A, Molinari F (2000) Cell-bound and extracellular carboxylesterases from Streptomyces: hydrolystic and synthetic activities. J App Microb 89: 870-875

19. Gao XG, Cao SG, Zhang KC (2000) Production, properties and application to nonaqueous enzymatic catalysis of lipase from a newly isolated Pseudomonas strain. Enzym Microb Technol 27:74-82

20. Gaur R, Gupta A, Khare SK (2008) Purification and characterization of lipase from solvent tolerant Pseudomonas aeruginosa PseA. Process Biochem 43:10401046

21. Gorman LAS, Dordick JS (1992) Organic solvents strip water off enzymes. Biotechnol Bioeng 39:392-397

22. Gulati R, Saxena RK, Gupta R, Yadav RP, Davidson WS (1999) Parametric optimisation of Aspergillus terreus lipase production and its potential in ester synthesis. Process Biochem 35:459-464

23. Gupta R, Gigras P, Mohapatra H, Goswami VK, Chauhan B (2003) Microbial $\alpha$ amylases: a biotechnological perspective. Process Biochem 38:1599-1616

24. Gupta R, Gupta N, Rathi P (2004) Bacterial lipases: an overview of production, purification and biochemical properties. Appl Microbiol Biotechnol 64:763-781. of lipase-secreting bacteria by deploying used frying oil as selective substrate. Enzym Microb Technol 26:40-44 
26. Kamini NR, Fujii T, Kurosu T, Iefuji H (2000) Production, purification and characterization of an extracellular lipase from Cryptococcus sp. S-2. Process Biochem 36:317-324

27. Kanwar L, Gogoi BK, Goswami P (2002) Production of a Pseudomonas lipase in $n$-alkane substrate and its isolation using an improved ammonium sulphate precipitation technique. Bioresour Technol 84:207-211

28. Klibanov AM (1997) Why are enzymes less active in organic solvents than in water? Trends Biotechnol 15:97-101

29. Kouker G, Jaeger KE (1987) Specific and sensitive plate assay for bacterial lipases. Appl Environ Microbiol 53:211-213

30. Large KP, Mirjalili N, Osborne M, Peacock LM, Zormpaidis V, Walsh M, Cavanagh ME, Leadlay PF, Ison AP (1999) Lipase activity in Streptomycetes. Enzym Microb Technol 25:569-575

31. Lee M-H, Lee CH, Oh TK, Song JK, Yoon JH (2006) Isolation and characterization of a novel lipase from a metagenomic library of tidal flat sediments: evidence for a new family of bacterial lipases. Appl Environ Microbiol 72:7406-7409

32. Lescic I, Vukelic B, Majeric-Elenkov M, Saenger W, Abramic M (2001) Substrate specificity and effects of water-miscible solvents on the activity and stability of extracellular lipase from Streptomyces rimosus. Enzym Microb Technol 29: 548-553 
33. Lima VMG, Krieger N, Mitchell DA, Baratti JC, Filippis I, Fontana JD (2004) Evaluation of the potential for use in biocatalysis of a lipase from a wild strain of Bacillus megaterium. J Mol Catal B: Enzym 31:53-61

34. Lin ES, Ko HC (2005) Glucose stimulates production of the alkaline-thermostable lipase of the edible basidiomycete Antrodia cinnamomea. Enzyme Microb Technol 37:261-265

35. Lin SF, Chiou CM, Tsai YC (1995) Effect of Triton X-100 on alkaline lipase production by Pseudomonas pseudoalkaligenes F-111. Biotechnol Lett 17:959962

36. Makhzoum A, Knapp JS, Owusu RK (1995) Factor affecting growth and lipase production by Pseudomonas fluorescens 2D. Food Microbiol 12:277-290

37. Mudgetti RE (1986) In: Demain AL, Solmen NA (ed) Manual of industrial biotechnology. Washington, DC: American Society for Microbiology, pp 66-83

38. Muralidhar RV, Chirumamila RR, Marchant R, Nigam P (2001) A response surface approach for the comparison of lipase production from Candida cylindracea using two different carbon sources. Biochem Eng J 9:17-23

39. Obido FJC, Okereke UO, Oyeka CA (1995) Influence of culture conditions on the production of lipase of Hendersonula toruloidea. Bioresour Technol 54:81-83. solvents. J Biosci Bioeng 91:109-16 realm of microbial lipases in biotechnology. Biotechnol Appl Biochem 29:119- 
42. Patel RN (2008) Synthesis of chiral pharmaceutical intermediates by biocatalysis.

609

610 Coord Chem Rev 252:659-701

43. Pencreac'h G, Baratti JC (2001) Comparison of hydrolytic activity in water and heptane for thirty-two commercial lipase preparations. Enzym Microb Technol 28:473-479

44. Rathi P, Saxena RK, Gupta R (2001) A novel alkaline lipase from Burkholderia cepacia for detergent formulation. Process Biochem 37:187-192

45. Ruchi G, Anshu G, Khare SK (2008) Lipase from solvent tolerant Pseudomonas aeruginosa strain: production optimization by response surface methodology and application. Bioresour Technol 99:4796-4802

46. Schmid RD, Verger R (1998) Lipases: interfacial enzymes with attractive applications. Angew Chem Int Ed Engl 37:1608-1633

47. Servin-Gonzalez L, Castro C, Perez C, Rubio M, Valdez F (1997) bldAdependent expression of the Streptomyces exfoliatus M11 lipase gene (lipA) is mediated by the product of a contiguous gene, lipR, encoding a putative transcriptional activator. J Bacteriol 179:7816-7826

48. Shirazi SH, Rahman SR, Rahman MM (1998) Production of extracellular lipases by Saccharomyces cerevisiae. World J Microbiol Biotechnol 14:595-597.

49. Swift S, Throup JP, Williams P, Salmond GP, Stewart GS (1996) Quorum sensing: a population-density component in the determination of bacterial phenotype. Trend Biochem Sci 21:214-219

50. Sztajer H, Maliszewka I, Wieczorek J (1988) Production of exogenous lipases by bacteria, fungi and actinomycetes. Enzym. Microb. Technol 10:492-497 
51. Tan T, Zhang M, Xu J, Zhang J (2004) Optimization of culture conditions and properties of lipase from Penicillium camembertii Thom PG-3. Process Biochem 39:1495-1502 producing Candida sp. and production of lipase by fermentation. Process Biochem 39:459-465 growth conditions for the production of extracellular lipase by Bacillus mycoides Ind J Microbiol 43:67-69

54. Wescott CR, Klibanov AM (1994) The solvent dependence of enzyme specificity. Biochim Biophys Acta 1206:1-9

55. Winkler UK, Stuckman M (1979) Glycogen, hyaluronate and some other polysaccharides greatly enhance the formation of exolipase by Serratia marcescens. J Bacteriol 138:663-679

56. Yang FC, Huang HC, Yang MJ (2003) The influence of environmental conditions on the mycelial growth of Antrodia cinnamomea in submerged cultures. Enzyme Microb Technol 33:395-402

57. Yu L, Xu Y, Yu X (2009) Purification and properties of a highly enantioselective L-menthyl acetate hydrolase from Burkholderia cepacia. J Mol Catal B Enzym $57: 27-33$ extracellular lipase Lip2 from Yarrowia lipolytica. Process Biochem 42:384-391 
59. Zaks A, Klibanov AM (1985) Enzyme-catalyzed processes in organic solvents. Proc Natl Acad Sci U S A 82:3192-3196 (2008) A novel proteolysis-resistant lipase from keratinolytic Streptomyces fradiae var. k11 Enzym Microb Technol 42:346-352

61. Zhao L, Xu J, Zhao J, Pan J, Wang Z (2008) Biochemical properties and potential applications of an organic solvent tolerant lipase isolated from Serratia marcescens ECU1010. Process Biochem 43:626-633 tryptophan residues of Humicola lanuginosa lipase on its thermal stability. J Biochim Biophys Acta 1547:329-338

664

665

666

667

668

669

670

671

672

673

674

675 
676 Table 1. Lipase screening of actinomycete strains in basal medium:

Amycolatopsis coloradensis DSM 44225

$(\mathrm{IU} / \mathrm{ml})$

681 A. fastidiosa DSM 43855

682 A. mediterranei DSM 43304

683 A. rubida DSM 44637

684 A. sulphurea DSM 46092

$685 \quad$ Nocardia araoensis DSM 44729

$686 \quad$ N. higoensis DSM 44732

$687 \quad$ N. kruckzakiae DSM 44877

688 Streptomyces amquistii NRRL B-1685

689 S. griseus subsp. griseus DSM 40236

690 S. coelicolor A3(2)

691 S. annulatus NRRL B-2000

692 S. arabicus NRRL B-1733

693 S. aurantiogriseus NRRL B-5416

694 S. rochei DSM 40231

695 S. aureoverticillatus NRRL B-3326

$0.046 \pm 0.001^{\mathrm{abc}}$

$0.059 \pm 0.004^{\mathrm{bc}}$

$0.040 \pm 0.002^{\mathrm{abc}}$

$0.086 \pm 0.012^{\mathrm{d}}$

$0.149 \pm 0.017^{\mathrm{f}}$

$0.062 \pm 0.008^{\mathrm{cd}}$

$0.031 \pm 0.002^{\mathrm{a}}$

$0.037 \pm 0.001^{\mathrm{abc}}$

$0.033 \pm 0.003^{\mathrm{a}}$

$0.046 \pm 0.001^{\mathrm{abc}}$

$0.116 \pm 0.010^{\mathrm{e}}$

$0.033 \pm 0.001^{\mathrm{a}}$

$0.051 \pm 0.002^{\mathrm{abc}}$

$0.030 \pm 0.001^{\mathrm{a}}$

$0.038 \pm 0.006^{\mathrm{abc}}$
$0.141+0.004^{\mathrm{ef}}$

$0.034 \pm 0.004^{\mathrm{ab}}$

696

S. althioticus NRRL B-3981

$0.037 \pm 0.004^{\mathrm{ab}}$

697 Data are means \pm standard deviations of three determinations. Column data followed by the same superscript

698 letter were not significantly different ( $p \leq 0.05$; by Tukey test)

$699{ }^{*}$ The RBA plates, after 6 days incubation at $28^{\circ} \mathrm{C}$, were exposed to UV (350 nm) to detect fluorescence:

700 orange fluorescence (+); no orange fluorescence (-).

$701{ }^{* *}$ Lipase activity in cell-free supernatant after $96 \mathrm{~h}$ growth in basal medium with $1 \%(\mathrm{v} / \mathrm{v})$ olive oil as inducer.

702

703

704

705

706

707

708

709 
711 Table 2. Effect of inoculum level on lipase production:

\begin{tabular}{lllll}
712 & Inoculum volume $(\%, \mathrm{v} / \mathrm{v})$ & Lipase $(\mathrm{IU} / \mathrm{ml})$ & Biomass $(\mathrm{mg} / \mathrm{ml})$ & Final $\mathrm{pH}$ \\
713 & 2 & $0.055 \pm 0.005^{\mathrm{a}}$ & $0.7 \pm 0.4^{\mathrm{a}}$ & $8.66 \pm 0.07$ \\
714 & 4 & $0.064 \pm 0.002^{\mathrm{ab}}$ & $1.0 \pm 0.3^{\mathrm{a}}$ & $8.82 \pm 0.06$ \\
715 & 6 & $0.079 \pm 0.010^{\mathrm{abc}}$ & $1.5 \pm 0.1^{\mathrm{a}}$ & $8.60 \pm 0.08$ \\
716 & 8 & $0.085 \pm 0.009^{\mathrm{bcd}}$ & $4.8 \pm 0.4^{\mathrm{b}}$ & $8.76 \pm 0.04$ \\
717 & 10 & $0.105 \pm 0.003^{\mathrm{d}}$ & $5.8 \pm 0.6^{\mathrm{b}}$ & $8.77 \pm 0.03$ \\
718 & 12 & $0.102 \pm 0.005^{\mathrm{cd}}$ & $5.6 \pm 0.7^{\mathrm{b}}$ & $8.73 \pm 0.04$ \\
\hline
\end{tabular}

$719{ }^{*}$ The shake flask experiments were performed in basal medium for $96 \mathrm{~h}$ at $28{ }^{\circ} \mathrm{C}, 130 \mathrm{rpm}$.

$720 \quad$ ** Data are means \pm standard deviations of three determinations. Column data followed by the same

721 superscript letter were not significantly different ( $p \leq 0.05$; by Tukey test). 
Table 3. Effect of inducers on lipase production:

Inducer Lipase

$(\mathrm{IU} / \mathrm{ml})$

Biomass

Final $\mathrm{pH}$

Natural oils $(1.0 \%, \mathrm{v} / \mathrm{v})$

Control $^{*}$

$0.081 \pm 0.004^{\mathrm{f}}$

Jojoba

$0.071 \pm 0.003^{\text {ef }}$

Corn

$0.052 \pm 0.002^{\text {cd }}$

(mg/ml)

Cottonseed

Grapeseed

$0.060 \pm 0.007^{\mathrm{de}}$

Groundnut

$0.046 \pm 0.001^{\mathrm{bc}}$

Linseed

$0.037 \pm 0.001^{\mathrm{b}}$

$0.128 \pm 0.004^{\mathrm{h}}$

Rapeseed

Soybean

$0.013 \pm 0.004^{\mathrm{a}}$

Sunflower

$0.014 \pm 0.001^{\mathrm{a}}$

$6.0 \pm 2.8^{\mathrm{ab}}$

$4.0 \pm 1.4^{\mathrm{a}}$

$4.5 \pm 3.5^{\mathrm{ab}}$

$7.90 \pm 0.03$

$4.5 \pm 0.7^{\mathrm{ab}}$

$8.71 \pm 0.04$

Surfactants $(0.5 \%, \mathrm{w} / \mathrm{v})$

$0.104 \pm 0.004^{\mathrm{g}}$

$2.5 \pm 0.7^{\mathrm{a}}$

$8.70 \pm 0.28$

$8.67 \pm 0.03$

$4.5 \pm 0.7^{\mathrm{ab}}$

$8.64 \pm 0.06$

$16.0 \pm 1.4^{\mathrm{b}}$

$7.01 \pm 0.01$

$2.5 \pm 0.7^{\mathrm{a}}$

$8.66 \pm 0.18$

Control $^{*}$

Span 40

$0.125 \pm 0.006^{\mathrm{e}}$

$1.5 \pm 0.7^{\mathrm{a}}$

$8.70 \pm 0.42$

Span 65

$0.031 \pm 0.003^{\mathrm{ab}}$

$11.5 \pm 2.1^{\mathrm{bc}}$

$7.81 \pm 0.07$

Span 80

$0.034 \pm 0.001^{\mathrm{b}}$

$5.5 \pm 0.1^{\mathrm{d}}$

$7.26 \pm 0.03$

$1.6 \pm 0.8^{\mathrm{ab}}$

$1.6 \pm 0.1^{\mathrm{ab}}$

$8.71 \pm 0.03$

Tween 20

$0.063 \pm 0.002^{\mathrm{d}}$

$4.7 \pm 0.8^{\mathrm{cd}}$

$8.68 \pm 0.04$

$0.056 \pm 0.003^{\text {cd }}$

$1.5 \pm 0.7^{\mathrm{ab}}$

$8.10 \pm 0.21$

Tween 21

$0.040 \pm 0.004^{\mathrm{bc}}$

$0.4 \pm 0.1^{\mathrm{a}}$

$8.75 \pm 0.03$

Tween 40

$0.053 \pm 0.003^{\text {cd }}$

$6.99 \pm 0.01$

Tween 80

$0.067 \pm 0.007^{\mathrm{d}}$

$1.2 \pm 0.1^{\mathrm{ab}}$

$8.74 \pm 0.03$

Triton X-100

$0.016 \pm 0.002^{\mathrm{a}}$

$3.2 \pm 0.1^{\text {bc }}$

$8.54 \pm 0.03$

763

764

The shake flask experiments were performed for $96 \mathrm{~h}$ at $28^{\circ} \mathrm{C}, 130 \mathrm{rpm}$. Data are means \pm standard

$7.26 \pm 0.06$

deviations of three determinations. Column data followed by the same superscript letter were not significantly

765 different ( $p \leq 0.05$; by Tukey test).

766

${ }^{*}$ Control refers to the basal medium with $1 \%(\mathrm{v} / \mathrm{v})$ olive oil as lipase inducer.

767

768

769

770

771

772

773

774

775 
Table 4. Effect of sugar additives and metal ions on lipase production:

Sugar additive $(1.0 \%, \mathrm{w} / \mathrm{v})$

\section{Contol ${ }^{*}$}

Arabinose

Dextrin

Fructose

Galactose

Glucose

Lactose

Mannitol

Maltose

Maltotetraose

\section{Mannose}

Raffinose

Rhamnose

Sorbitol

Sucrose

Starch

Xylose

Metal ions (\%,w/v)

Control $^{* *}$ $\mathrm{Fe}^{3+}(0.05 \%)$

$\mathrm{Ca}^{2+}(0.05 \%)$

$\mathrm{Mg}^{2+}(0.025 \%)+\mathrm{Fe}^{3+}(0.025 \%)$

$\mathrm{Fe}^{3+}(0.025 \%)+\mathrm{Ca}^{2+}(0.025 \%)$

$\mathrm{Mg}^{2+}(0.025 \%)+\mathrm{Ca}^{2+}(0.025 \%)$

Lipase activity
(IU/ml)

Biomass Final $\mathrm{pH}$
$(\mathrm{mg} / \mathrm{ml})$

$0.132 \pm 0.007^{\text {ab }}$
$0.158 \pm 0.013^{\text {abc }}$
$0.194 \pm 0.042^{\text {bcd }}$
$0.467 \pm 0.007^{\mathrm{j}}$
$0.349 \pm 0.007^{\text {fghi }}$
$0.317 \pm 0.019^{\text {ffgh }}$
$0.399 \pm 0.021^{\text {hij }}$
$0.343 \pm 0.035^{\text {fghi }}$
$0.424 \pm 0.071^{\mathrm{jj}}$
$0.237 \pm 0.007^{\mathrm{cde}}$
$0.266 \pm 0.003^{\text {defg }}$
$0.350 \pm 0.007^{\text {ghi }}$
$0.211 \pm 0.014^{\text {bcd }}$
$0.410 \pm 0.006^{\mathrm{hij}}$
$0.253 \pm 0.014^{\mathrm{cdef}}$
$0.078 \pm 0.007^{\mathrm{a}}$
$0.417 \pm 0.008^{\mathrm{ij}}$

\section{$0.096 \pm 0.009^{\mathrm{a}}$}

$0.109 \pm 0.005^{\mathrm{a}}$

$0.102 \pm 0.001^{\mathrm{a}}$

$0.097 \pm 0.003^{\mathrm{a}}$

$0.104 \pm 0.001^{\mathrm{a}}$
$8.66 \pm 0.01$

$8.90 \pm 0.08$

$8.57 \pm 0.07$

$8.65 \pm 0.04$

$8.81 \pm 0.03$

$8.69 \pm 0.03$

$8.72 \pm 0.03$

$8.64 \pm 0.03$

$8.79 \pm 0.01$

$8.49 \pm 0.03$

$8.64 \pm 0.03$

$8.71 \pm 0.03$

$8.73 \pm 0.06$

$8.66 \pm 0.04$

$8.88 \pm 0.03$

$8.76 \pm 0.03$

$8.78 \pm 0.04$

$5.7 \pm 0.1^{\mathrm{ab}}$

$9.8 \pm 0.5^{\text {cdefg }}$

$8.70 \pm 0.10$

$6.1 \pm 0.4^{\mathrm{a}}$

$8.62 \pm 0.07$

$6.9 \pm 0.5^{\mathrm{a}}$

$8.75 \pm 0.06$

$5.8 \pm 0.4^{\mathrm{a}}$

$8.60 \pm 0.07$

$6.1 \pm 1.8^{\mathrm{a}} \quad 8.82 \pm 0.04$

$5.8 \pm 0.3^{\mathrm{a}}$

$8.76 \pm 0.03$

804 The shake flask experiments were performed for $96 \mathrm{~h}$ at $28^{\circ} \mathrm{C}, 130 \mathrm{rpm}$. Data are means \pm standard

805

deviations of three determinations. Column data followed by the same superscript letter were not significantly

806 different ( $p \leq 0.05$; by Tukey test).

807

${ }^{*}$ Control refers to the basal medium in the absence of any sugar additive.

808

${ }^{* *}$ Control with $0.05 \%(\mathrm{w} / \mathrm{v})$ of $\mathrm{Mg}^{2+}$ in the basal medium.

809

810

811

812

813

814

815 


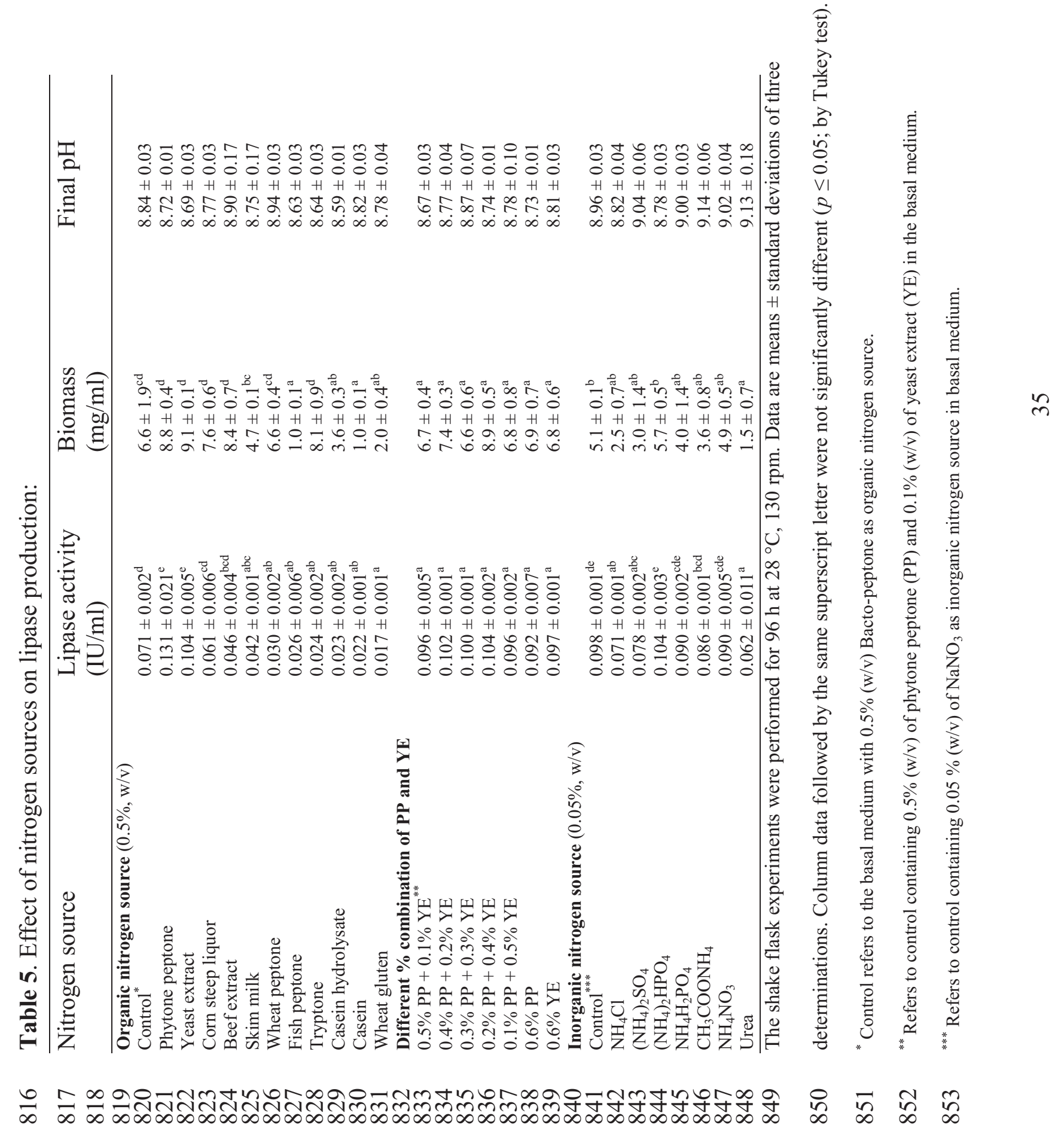


854 Table 6. Stability of $A$. mediterranei DSM 43304 lipase in organic solvents:

Organic solvent $\quad \log P \quad$ Relative activity (\%)

861

862

863

864

865

866

867

868

869

870

871

872

873

874

875

876

Control

After $1 \mathrm{~h}$

After $24 \mathrm{~h}$

\section{DMSO}

DMF

Methanol

$-1.3$

$100.0 \pm 1.2$

$100.0 \pm 0.6$

2-propanol

$-1.04$

$109.4 \pm 2.3$

$89.6 \pm 3.7^{\mathrm{a}}$

Ethanol

$-0.76$

$131.3 \pm 6.3^{\mathrm{a}}$

$137.6 \pm 0.9^{\mathrm{a}}$

Acetone

$-0.28$

$129.5 \pm 2.8^{\mathrm{a}}$

$136.5 \pm 0.6^{\mathrm{a}}$

$112.6 \pm 2.5^{\mathrm{a}}$

$t$-Butanol

$-0.24$

$109.6 \pm 2.0$

$115.9 \pm 3.4^{\mathrm{a}}$

Pyridine

$-0.23$

Diethyl ether

0.35

$131.7 \pm 5.2^{\mathrm{a}}$

$134.6 \pm 2.8^{\mathrm{a}}$

$96.3 \pm 5.8$

$72.4 \pm 3.5^{\mathrm{a}}$

$75.4 \pm 3.4^{\mathrm{a}}$

$49.8 \pm 2.8^{\mathrm{a}}$

Benzene-

Chloroform $\quad 2.0$

$116.8 \pm 2.6^{\mathrm{a}}$

$136.9 \pm 1.8^{\mathrm{a}}$

Toluene

$169.7 \pm 2.0^{\mathrm{a}}$

$169.1 \pm 1.2^{\mathrm{a}}$

Carbon tetrachloride $\quad 2.64$

$113.8 \pm 6.3$

$153.3 \pm 3.6^{\mathrm{a}}$

$134.1 \pm 2.2^{\mathrm{a}}$

$137.2 \pm 3.7^{\mathrm{a}}$

$157.2 \pm 2.8^{\mathrm{a}}$

Cyclohexene

$138.6 \pm 2.3^{\mathrm{a}}$

$117.6 \pm 0.9^{\mathrm{a}}$

p-Xylene

2.86

$161.9 \pm 2.0^{\mathrm{a}}$

$109.3 \pm 2.2$

$n$-Hexane

$156.7 \pm 3.2^{\mathrm{a}}$

$133.7 \pm 2.2^{\mathrm{a}}$

Dodecane

3.5

Petroleum ether

$115.5 \pm 3.3^{\mathrm{a}}$

$111.7 \pm 4.3^{\mathrm{a}}$

6.6

$140.5 \pm 2.6^{\mathrm{a}}$

$68.0 \pm 3.9^{\mathrm{a}}$

$123.7 \pm 2.2^{\mathrm{a}}$

Lipase preparation was incubated in each organic solvent $(25 \%)$ at $30{ }^{\circ} \mathrm{C}$ for 1 and $24 \mathrm{~h}$.

878

Values represent the mean of three replicates.

879

880

881

882

883

884

885

886

887

888

889

890

891

892

893

894

895

896

897

898

899

900

901 
902 Table 7. Effect of metal ions/effectors on stability of $A$. mediterranei DSM 4334 lipase:

\begin{tabular}{|c|c|}
\hline Metal ion/effector (1 mM) & Relative activity (\%) \\
\hline Control & $100.0 \pm 1.0$ \\
\hline $\mathrm{Ag}^{+}$ & $88.2 \pm 5.5$ \\
\hline $\mathrm{Ba}^{2+}$ & $99.1 \pm 1.0$ \\
\hline $\mathrm{Ca}^{2+}$ & $91.1 \pm 4.5$ \\
\hline $\mathrm{Co}^{2+}$ & $91.1 \pm 0.6$ \\
\hline $\mathrm{Cu}^{2+}$ & $100.2 \pm 5.2$ \\
\hline $\mathrm{Fe}^{3+}$ & $115.2 \pm 7.1^{\mathrm{a}}$ \\
\hline $\mathrm{Hg}^{2+}$ & $20.0 \pm 3.2^{\mathrm{a}}$ \\
\hline $\mathrm{Li}^{+}$ & $79.2 \pm 2.6^{\mathrm{a}}$ \\
\hline $\mathrm{Mg}^{2+}$ & $81.3 \pm 3.5^{\mathrm{a}}$ \\
\hline $\mathrm{Mn}^{2+}$ & $112.9 \pm 5.2$ \\
\hline $\mathrm{Ni}^{2+}$ & $95.2 \pm 1.9$ \\
\hline $\mathrm{Pb}^{2+}$ & $97.0 \pm 0.6$ \\
\hline $\mathrm{Zn}^{2+}$ & $95.9 \pm 1.6$ \\
\hline $\mathrm{NH}_{4}^{+}$ & $103.8 \pm 1.8$ \\
\hline EDTA & $103.6 \pm 1.6$ \\
\hline SDS & $100.0 \pm 2.9$ \\
\hline Urea & $88.1 \pm 2.9$ \\
\hline PMSF & $85.3 \pm 3.2^{\mathrm{a}}$ \\
\hline
\end{tabular}

923 The lipase preparation was incubated in the presence of various compounds at $60{ }^{\circ} \mathrm{C}$ for $10 \mathrm{~min}$.

924 Values represent the mean of three replicates.

$925{ }^{a}$ Significantly different $(p \leq 0.05$; by Tukey test) with respect to the control. 


\section{Figure captions:}

954 Figure 1.

955 Screening for lipolytic actinomycete strains on rhodamine B agar.

956 a. Amycolatopsis coloradensis DSM 44225; b. A. amakusaensis NRRL B-3351; c. A.

957 fastidiosa DSM 43855; d. A. mediterranei DSM 43304; e. A. rubida DSM 44637; f. $A$.

958 sulphurea DSM 46092; g. Nocardia araoensis DSM 44729; h. N. higoensis DSM 44732; i.

959 N. kruckzakiae DSM 44877; j. Streptomyces amquistii NRRL b-1685, k. S. griseus subsp.

960 griseus DSM 40236; I. S. coelicolor A3(2); m. S. annulatus NRRL B-2000; n. S. arabicus

961 NRRL B-1733; o. S. aurantiogriseus NRRL B-5416; p. S. rochei DSM 40231; q. S.

962 aureoverticillatus NRRL B-3326; r. S. althioticus NRRL B-3981

963 Figure 2.

964 Time course of lipase production by $A$. mediterranei DSM 43304. Basal medium was

965 seeded with $10 \%(\mathrm{v} / \mathrm{v})$ inoculum and incubated at $28^{\circ} \mathrm{C}$ for $192 \mathrm{~h}$ at $130 \mathrm{rpm}$. Samples

966 were withdrawn at $24 \mathrm{~h}$ intervals to monitor biomass ( $\square), \mathrm{pH}(\circ)$ and lipase activity ( $\square)$ in

967 cell-free supernatants.

968 Figure 3.

969 Effect of incubation temperature on lipase production ( $\square$ ) and biomass ( $\square)$ during growth of

970 A. mediterranei DSM 43304 in shake flask cultures after $96 \mathrm{~h}$ of incubation at temperatures

971 varying from $20-45^{\circ} \mathrm{C}$.

$972 \quad$ Figure 4.

973 Effect of initial $\mathrm{pH}$ on lipase production ( $\square$ ) and biomass ( $\square$ ) in shake flask cultures after 96

$974 \mathrm{~h}$ of cultivation with initial medium $\mathrm{pH}$ varying from 5.0 to 9.0. 


\section{Figure 5.}

977 Effect of temperature on A. mediterranei DSM 43304 lipase activity (ם) and stability ( $\square$ ). 978 Assay conditions: $30-90^{\circ} \mathrm{C}, 50 \mathrm{mM}$ Tris- $\mathrm{HCl}$ buffer $\mathrm{pH}$ 8.0. Thermal stability of the 979 enzyme was studied by incubating the enzyme at various temperatures $(30,40,50,60,70$, 98080 and $90{ }^{\circ} \mathrm{C}$ ) for $3 \mathrm{~h}$. Residual activity (\%) at each temperature was calculated relative to 981 that at $0 \mathrm{~h}$ as $100 \%$.

\section{Figure 6.}

983 Effect of pH on A. mediterranei DSM 43304 lipase activity (ロ) and stability ( $\square$ ).

984 For stability studies, residual activities were measured after $24 \mathrm{~h}$ incubation at $4{ }^{\circ} \mathrm{C}$ in the 985 presence of different buffers: $\mathrm{HCl}-\mathrm{KCl}(\mathrm{pH} 2.0)$, sodium citrate $(\mathrm{pH} 3.0)$, succinate- $\mathrm{NaOH}$ 986 ( $\mathrm{pH} 4.0$ and 5.0), sodium phosphate ( $\mathrm{pH} 6.0$ and 7.0), Tris- $\mathrm{HCl}(\mathrm{pH} 8.0$ and 9.0) and 987 glycine- $\mathrm{NaOH}(\mathrm{pH} 10.0)$, all buffers at $50 \mathrm{mM}$ concentration. Assay conditions: $60^{\circ} \mathrm{C}$, 988 Tris- $\mathrm{HCl}$ buffer, $\mathrm{pH} 8.0,50 \mathrm{mM}$. The activities were compared to the activity determined 989 in $50 \mathrm{mM}$ Tris- $\mathrm{HCl}$ buffer, $\mathrm{pH} 8.0$ without pre-incubation.

990

991

992

993

994

995

996

997

998 
999 Figure 1.

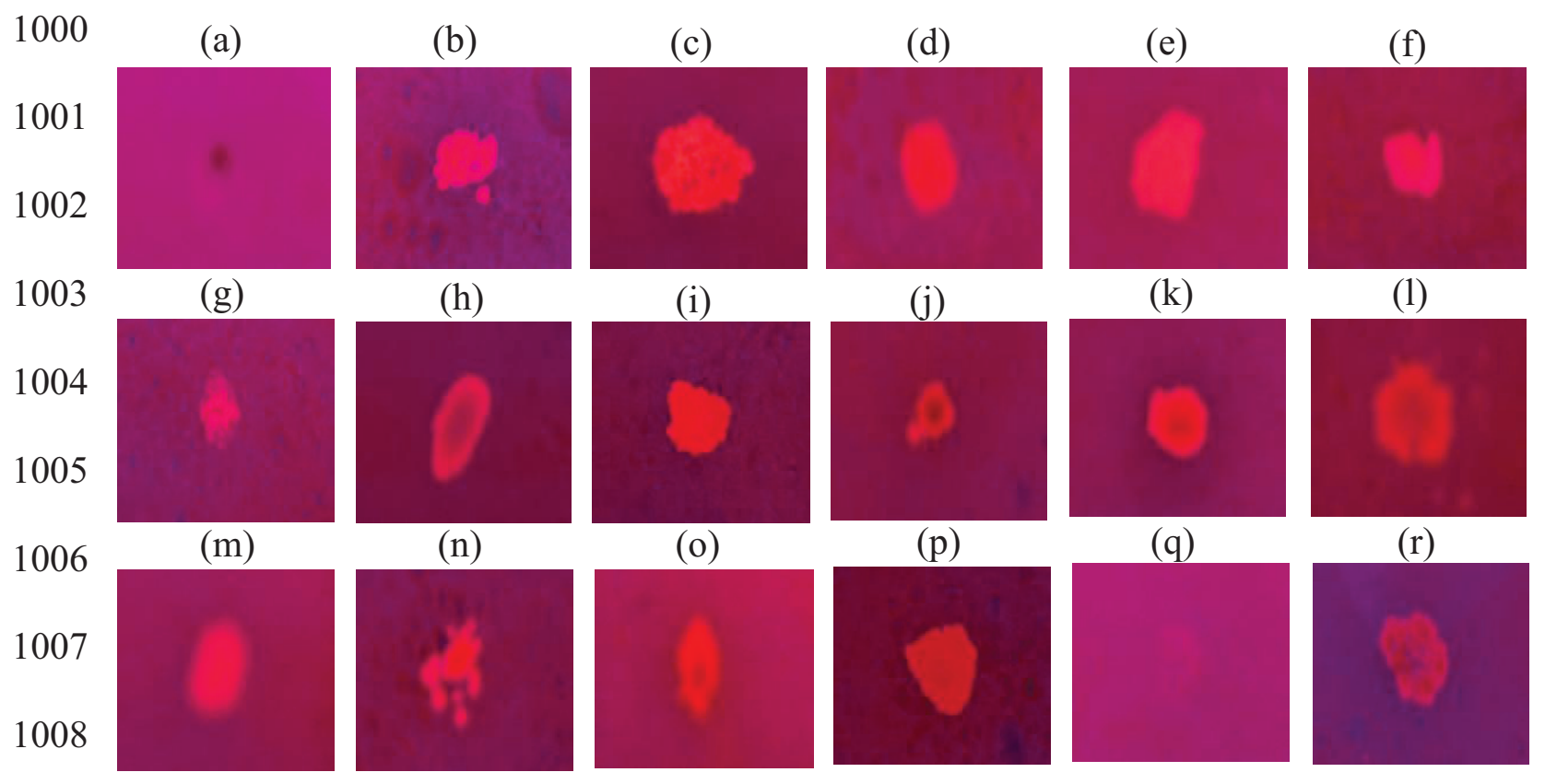

1009

1010

1011

1012

1013

1014

1015

1016

1017

1018

1019

1020

1021 
Figure 2.

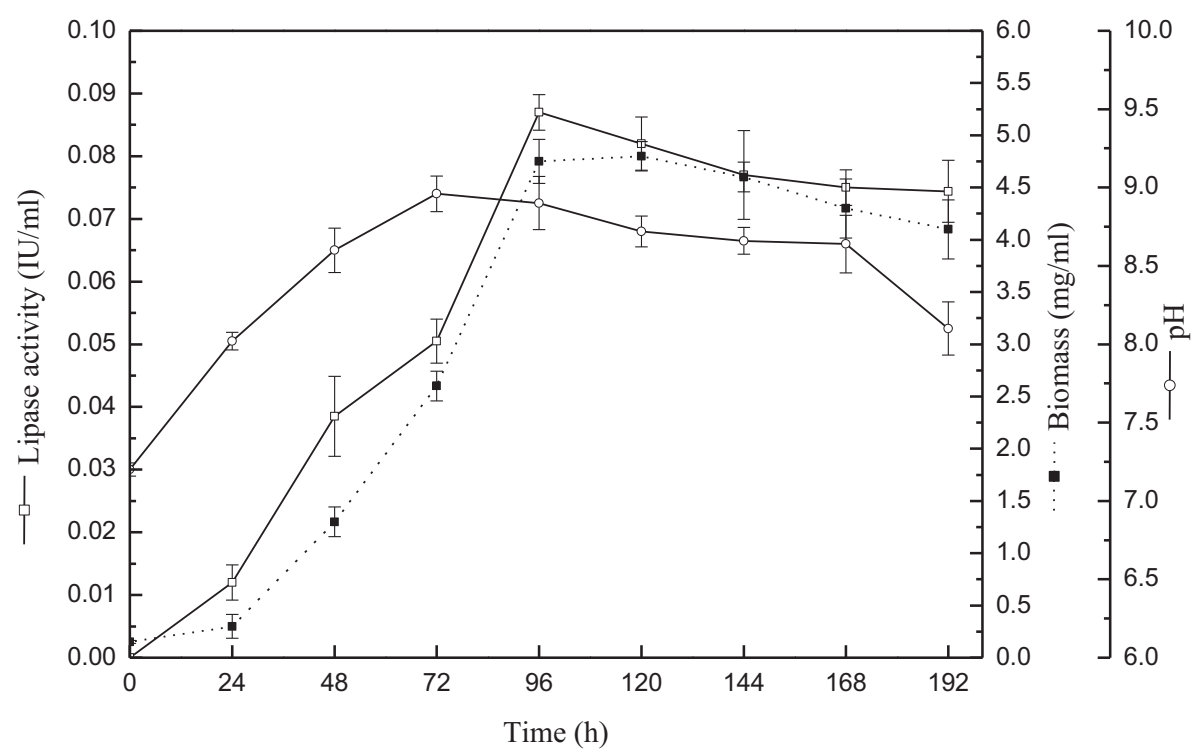

1023

1024

1025

1026

1027

1028

1029

1030

1031

1032

1033

1034

1035 
Figure 3.

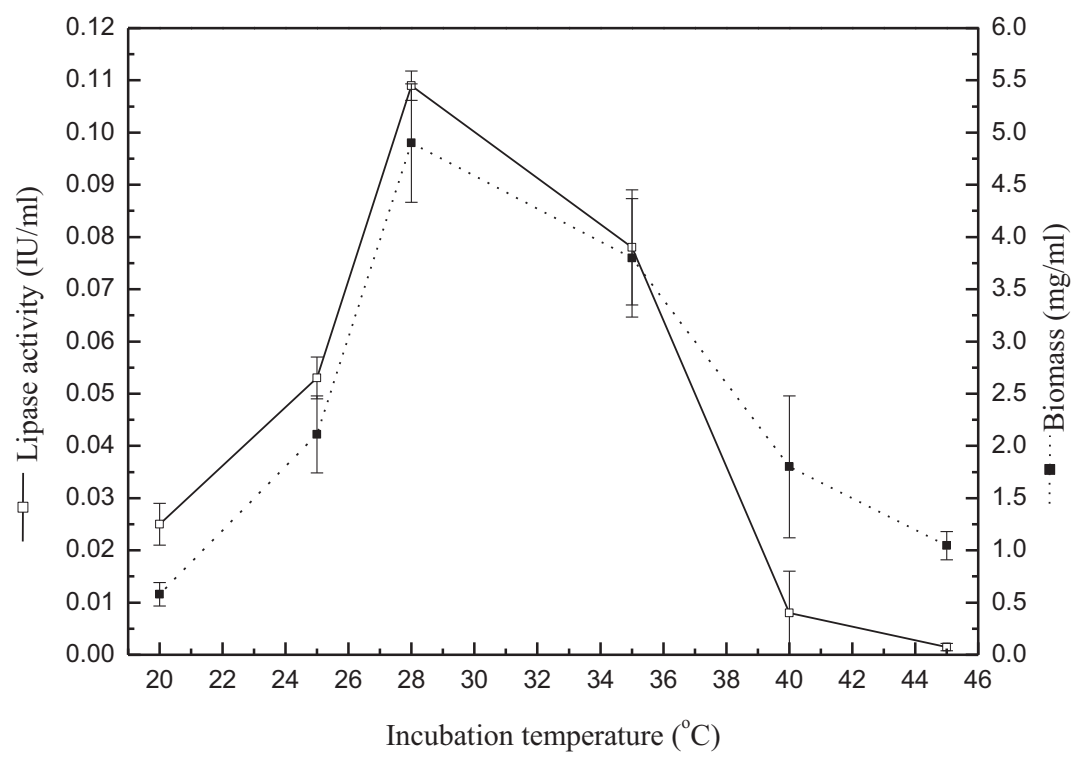

1037

1038

1039

1040

1041

1042

1043

1044

1045

1046

1047

1048

1049 
Figure 4.

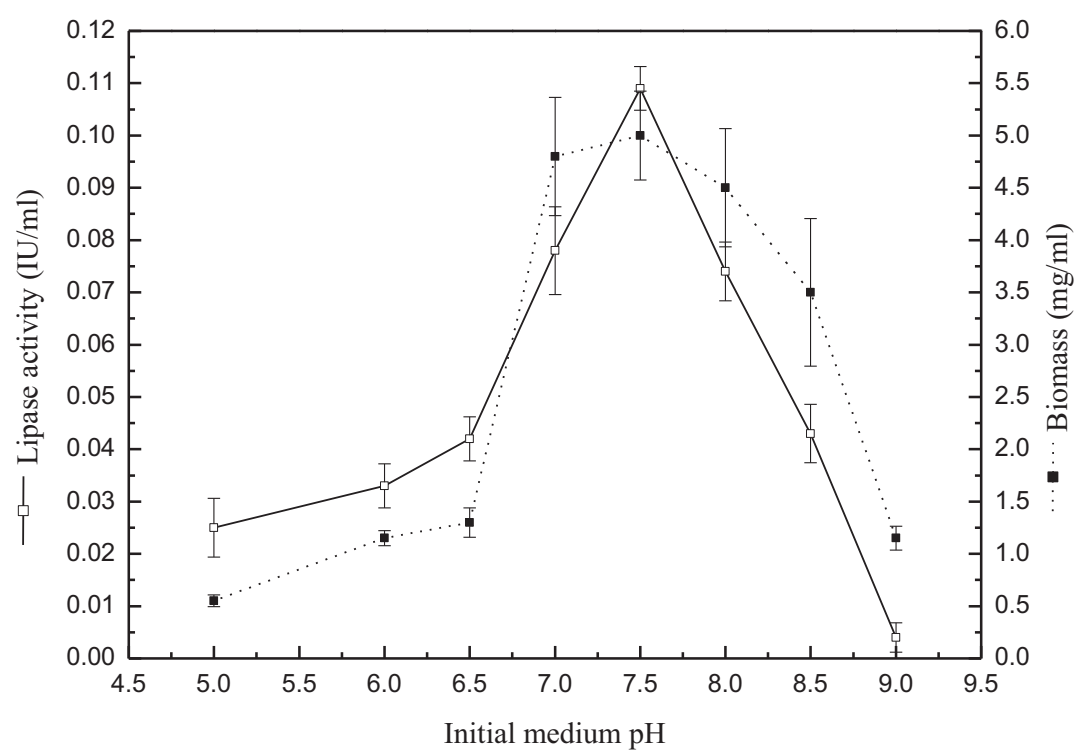

1051

1052

1053

1054

1055

1056

1057

1058

1059

1060

1061

1062

1063 
1064 Figure 5.

1065

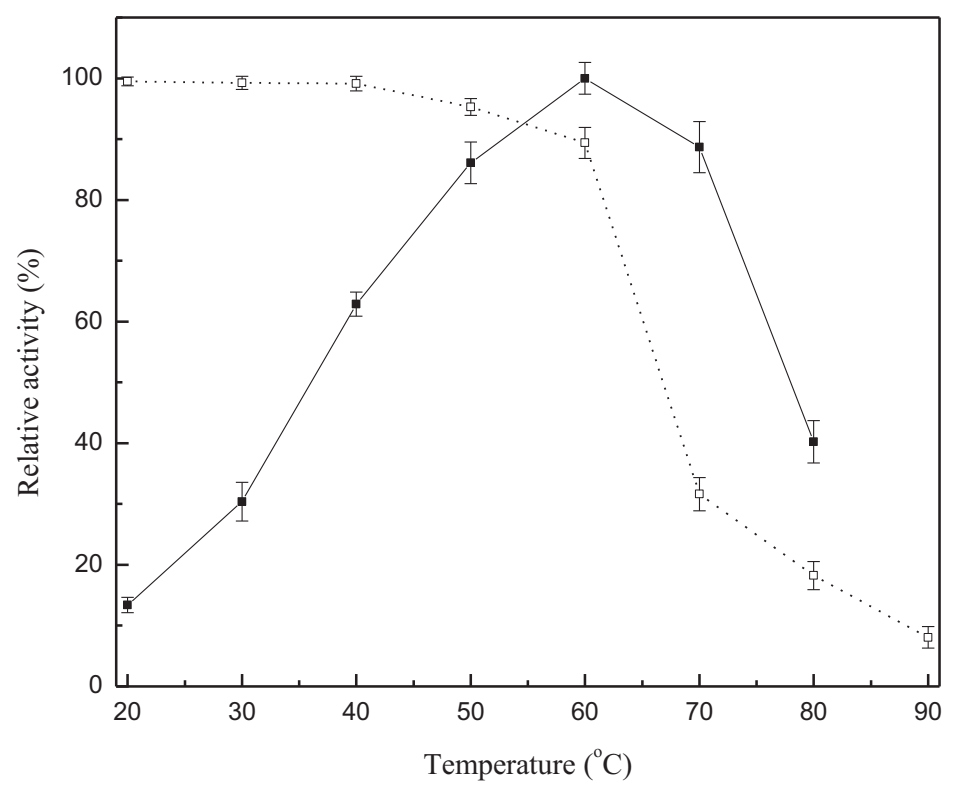

1066

1067

1068

1069

1070

1071

1072

1073

1074

1075

1076

1077 
$1078 \quad$ Figure 6.

1079

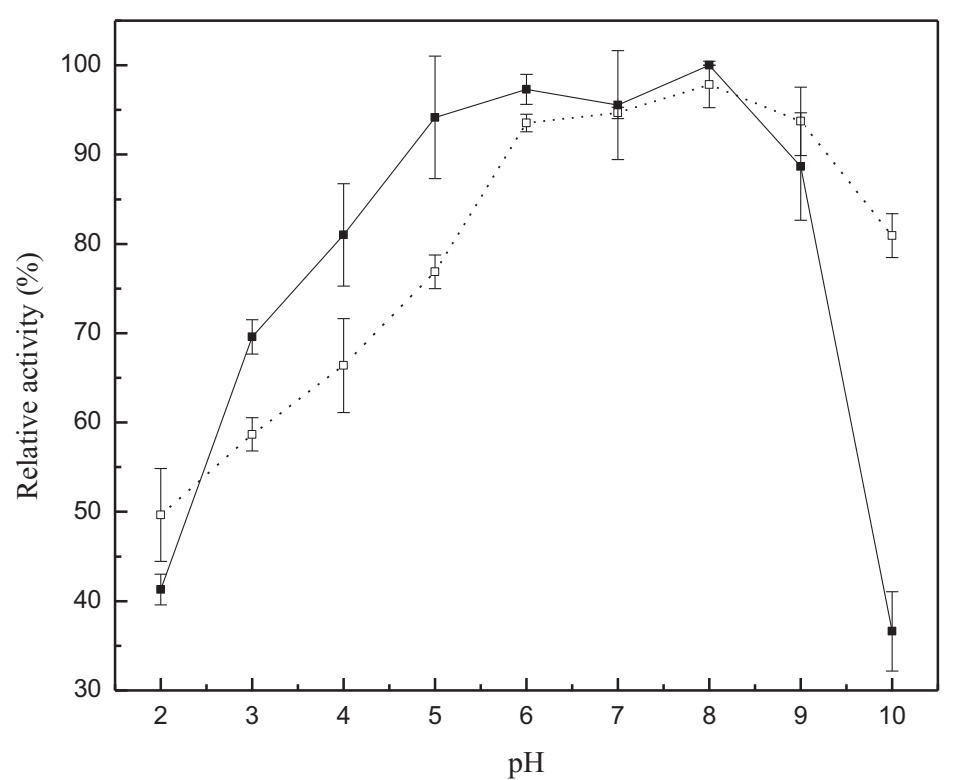

1080

1081

1082 